\title{
THE HIGH COURT OF AUSTRALIA AND THE SUPREME COURT OF THE UNITED STATES - A CENTENARY REFLECTION*
}

\author{
The Hon Justice Michael Kirby AC $C M G^{* *}$
}

\section{INTRODUCTION}

In October 2003 in Melbourne, the High Court of Australia celebrated the centenary of its first sitting. According to the Australian Constitution, it is the "Federal Supreme Court" of the Australian Commonwealth. ${ }^{1}$ Although the Constitution envisaged the establishment of the High Court, the first sitting of the new court did not take place until a statute had provided for the court and the appointment of its first Justices. They took their seats in a ceremony held in the Banco Court in the Supreme Court of Victoria on 6 October 1903. Exactly a century later, the present Justices assembled in the same courtroom for a sitting to mark the first century of the Court.

In the course of the century, the Australian Justices have paid close attention to the decisions of the Supreme Court of the United States. The similarities between the Australian Constitution and that of the United States from which many basic ideas were borrowed made such attention inevitable. For the Australian colonists fashioning their own Constitution, the United States Constitution was "an incomparable model".

Indirectly, the Australian colonies owed their existence to the American Revolution and the work of the colonists who met at the Constitutional Convention in Philadelphia in 1787, there establishing a Constitution of shared powers, with a Supreme Court and federal judiciary to uphold the federal compact. But for the loss of the American colonies, it is unlikely that the government of King George III would have been sufficiently interested to

* Based on a lecture given to the Washington College of Law, American University, Washington, 24 September 2003.

** Justice of the High Court of Australia.

${ }^{1}$ Commonwealth of Australia Constitution Act 1900 (UK); 63 \& 64 Vict c 12. In form, the Australian Constitution was appended to the Imperial Act. In reality, it was virtually entirely drafted in Australia, adopted at Constitutional Conventions of elected representatives and approved by referenda conducted throughout the Australian colonies.

2 O Dixon "The Law and the Constitution", in O Dixon Jesting Pilate (2nd ed) (hereafter “Jesting Pilate”) (New York, Hein, 1997) 44. 
establish the colony of New South Wales, out of which the Australian nation grew. That development is thus one of those accidents of history that presents the puzzle as to what would have been the fate of the Great South Land had it not been for the American Revolution of 1776.

That revolution had dual consequences, important for Australia's future. First, it necessitated the urgent investigation of alternative places to which Britain could send the convicts who had formerly been sent to the American colonies. Secondly, the British government was sufficiently shocked by the loss of the American colonies that it modified its colonial policy, at least with respect to those settled by colonists who came from the British Isles. To some extent, the British learned the lessons that the American colonists had taught. These included the ultimate right of people to alter, or to abolish, the form of government imposed upon them and to institute a new government to correct intolerable wrongs; the need to avoid despotism lest those subject to it throw off such government and provide new protections for their security; and the necessity without delay, to establish (at least in settler societies) a form of government similar to that enjoyed at home by the commons of England.

When, after 1776, the British Government lost the right to deposit unwanted convicts in the American colonies, the necessity to find an alternative venue arose. Various possibilities in Africa were canvassed. Eventually, those with the responsibility of deciding these things remembered the report of the journey to the South Pacific by Captain James Cook. Thus was born the idea of establishing a new colony in Australia. ${ }^{3}$ It was to be a penal colony.

Australians are therefore children of the American Revolution. From the start, their legal history was connected to that of the United States. The evolution of British colonial policy had the consequence of avoiding the need for revolution in Australia. From the beginning, the example of the legal and judicial system of the United States remained before the Australian colonists. When, eventually, self-government began to spread to the Australian colonies after the $1850 \mathrm{~s},{ }^{4}$ part of the impetus for change was the ever-present example provided by the United States Constitution and the governmental and judicial systems that it had created.

3 A Castles An Australian Legal History, (Sydney, Law Book Company, 1982) 20-31.

${ }^{4}$ Ibid 165, 401-402. Responsible government was granted in New South Wales in 1855 by the establishment of an elected Lower House of Parliament (the Legislative Assembly). This followed an earlier partial grant of self-government in 1842 by an Imperial Act that provided for a Legislative Council, two-thirds of whose members would be elected on a franchise limited by a property qualification. There were similar moves in the other Australian States; cf Yourgala v Western Australia (2001) 207 CLR 344. 
The similarities and differences between the constitutional arrangements adopted in Australia and the United States have been explored by earlier writers. ${ }^{5}$ One way of understanding ourselves is to endeavour to see ourselves as others see us. We do this not so much in tribute to others as to reflect upon ourselves holding up the experience of others as a mirror by which we may see our own concerns reflected in slightly different forms. Lawyers of the common law tradition share the advantages of the English language and a particular system for solving legal disputes. They enjoy institutions with common features. This linguistic and institutional history brings with it not only similar approaches to the resolution of problems but shared values and a shared methodology for resolving conflict in society.

It was in the Royal Courts in London that the idea of common law institutions took hold. Out of the work of those courts came not only the resolution of particular disputes but precedents which, recorded and, followed by later judges, helped to resolve similar disputes. The idea of the public trial, conducted before a judge and a jury was so powerful in the English imagination that when they had their own civil war and decided to rid themselves of an autocratic king, they followed the format of a jury trial, however flawed. ${ }^{6}$ Even in such a matter, the idea of constitutionalism and the rule of law could not be ignored.

Because the United States and Australia share the same language and a great part of the same legal tradition derived from England, it is useful to compare their judicial institutions and legal doctrines. This is especially so in the case of Australia and in respect of the judicial branch of government, because, save in certain particular matters, the founders of the Australian Commonwealth copied from Art III of the United States Constitution many of its ideas when they were drafting Ch III of the Australian Constitution. ${ }^{7}$ Moreover, from the beginning of the High Court of Australia, the Justices borrowed from United States precedents of which, especially in the early years, they were very familiar. ${ }^{8}$

The high level of similarity of history, culture and law may therefore sometimes make it useful both to the United States and Australia to be aware of

5 O Dixon “Two Constitutions Compared” in Jesting Pilate (1997) esp 100-112; F C Hutley, "The Legal Traditions of Australia as Contrasted with those of the United States" (1981) 55 Australian Law Journal 63.

${ }^{6}$ cf M D Kirby “The Trial of King Charles I: Defining Moment for our Constitutional Liberties” (1999) 73 Australian Law Journal 577, where the story is told.

7 O Dixon "Two Constitutions Compared” in Jesting Pilate, 100 at 101.

8 They were specially acquainted with James Bryce's The American Commonwealth: see M N C Harvey "James Bryce, 'The American Commonwealth', and the Australian Constitution” (2002) 76 Australian Law Journal 362. 
what is happening in the courts of the other country. Developments that occur there may occasionally be followed. Sometimes, even if not followed, a consideration of the experience of a similar constitutional system requires us to clarify our own thinking and to justify our points of difference, if only to ourselves.

\section{SIMILARITIES}

\section{Judicial power and federal powers:}

The first similarity between the Australian High Court and the Supreme Court of the United States concerns the role of the two courts. In any written Constitution, but particularly a federal one that divides power between different parts of the same polity, it is essential to have an umpire. There must be an authoritative means of determining where power lies. In the case of dispute, it is imperative to know whether a particular law or official or judicial act, is valid. In both the Australian Constitution and the Constitution of the United States, the federal supreme court has the responsibility ultimately to decide such matters. ${ }^{9}$

At different times in the history of a federation, different views will prevail concerning the respective powers of the central (or federal) lawmakers and office-holders and those of the subnational polities, in Australia as in the United States, the States. At the beginning of federation in Australia, drawing on late nineteenth century United States cases, the federal Constitution was seen as a contract between coordinate partners (the Commonwealth and the States). In accordance with the written text of the Constitution, each component enjoyed substantially equal responsibility for the good government of the people. The three original Justices of the High Court of Australia drew an inference from the federal structure of the Constitution, that certain powers were reserved to the State legislatures so that, by the use of its express grants of legislative power, the Federal Parliament could not use its powers to invade the lawmaking functions inferentially reserved to the States. ${ }^{10}$

It did not take long for the new national Parliament to put this doctrine to the test by the exercise of federal lawmaking power in a way seen to intrude into presumed State functions. The entry of Australia into the First World War in

\footnotetext{
9 O Dixon “Government Under the American Constitution” in O Dixon Jesting Pilate (1997).

${ }^{10}$ D'Emden v Pedder (1904) 1 CLR 91; Deakin $v$ Webb (1904) 1 CLR 585; Webb v Outrim [1907] AC 81 (PC); Baxter v Commissioners of Taxation (1907) 4 CLR 1087; Austin v The Commonwealth (2003) 77 ALJR 491; 195 ALR 321.
} 
1914 led to the use of the defence power ${ }^{11}$ in ways that challenged the previous assumptions about the "reserved powers" of the States. Under the defence power, the High Court upheld a broad ambit of lawmaking as claimed by the Federal Parliament to regulate the economy in ways that would otherwise have been unavailable. War made the difference, as so often it does. ${ }^{12}$

Before long, new appointees to the High Court of Australia questioned the notion of the reserved powers of the States. Eventually, in 1920, in the Engineers' Case, ${ }^{13}$ the majority of the Court rejected the doctrine of implied State immunities. The Court held that, if federal legislation were within the ambit of a grant of power to the Federal Parliament, broadly construed as befitted a Constitution, no implication arose from the federal structure of the Constitution that would, on its own, be sufficient to invalidate such a law. This charter for national lawmaking has subsequently been qualified somewhat by an elusive doctrine based on the constitutional necessity that the States should continue to exist, should perform their envisaged constitutional functions, and should not be destroyed or significantly prevented by federal law from discharging their functions as States. ${ }^{14}$ The Engineers' Case was nonetheless a most important charter for the lawmaking power of the Federal Parliament. As in the United States, the highest court has generally upheld the validity of federal legislation against State constitutional challenges. ${ }^{15}$ Only recently in Australia, and usually in relation to implications derived from Chapter III (the Judicature), has the federal lawmaking power taken something of a battering. ${ }^{16}$

\section{Constitutional and judicial review:}

There is no express grant of power to the High Court of Australia, or any other Australian court or body, to invalidate federal or State law as unconstitutional. There are systems of government that assign such ultimate responsibilities in this regard to the legislature. The Hong Kong Special Administrative Region discovered this when the People's Republic of China insisted that the ultimate powers of supervision of certain "constitutional"

11 Australian Constitution, s 51(vi).

${ }^{12}$ Farey v Burvett (1916) 21 CLR 433; South Australia v The Commonwealth (1942) 65 CLR 373; O Dixon, “Aspects of Australian Federalism” in Jesting Pilate, 113 at 121-122.

${ }^{13}$ Amalgamated Society of Engineers v Adelaide Steamship Co (1920) 28 CLR 129. For

a contemporary, critical commentary see G de Q Walker, "The Seven Pillars of Centralism: Engineers' Case and Federalism” (2002) 76 Australian Law Journal 678.

${ }^{14}$ Melbourne Corporation v The Commonwealth (1947) 74 CLR 31.

${ }^{15}$ O Dixon “Aspects of Australian Federalism” in Jesting Pilate 113 at 116-121.

${ }^{16}$ Re Wakim; Ex parte McNally (1999) 198 CLR 511; Bond v The Queen (2000) 201 CLR 213; Hughes v The Queen (2000) 202 CLR 535; cf Gould v Brown (1998) 193 CLR 346. 
decisions affecting Hong Kong after the British handover, belonged to the Standing Committee of the National People's Congress of China, not to a court. ${ }^{17}$ In a sense, the recognition until now of the House of Lords, as a kind of committee or board of the British Parliament, and of the Judicial Committee of the Privy Council as an expert legal body advising the British monarch, continue a model of ultimate resolution of legal questions in the legislature or the executive, not in a separate judiciary.

In the case of the British institutions, the symbolism does not reflect the current political or legal realities. Many of the Law Lords now rarely take part in political debates in the legislative chamber. Some never do. ${ }^{18}$ Although Privy Council determinations are traditionally expressed in the terms of "humble advice" to the monarch there is no occasion in modern history where the monarch has not accepted that advice. As in so many features of the British Constitution, appearances belie reality. Proposals to abolish the present arrangements and create a Supreme Court for the United Kingdom are under active consideration in late 2003. However, the existence of alternative models for ultimate decision-making in important constitutional contests, indicates that, without an express grant of authority for judges to have the last word, it was by no means inevitable that it would turn out that way.

Global constitutionalism therefore owes a great debt to the decision of the United States Supreme Court in Marbury $v$ Madison. ${ }^{19}$ By that decision, the Supreme Court, through the voice of Chief Justice Marshall, asserted the court's power to rule conclusively on the validity of the distribution of constitutional powers between the United States Congress and the States.

17 The power of the National People's Congress to make laws for Hong Kong, inconsistent with the Basic Law was upheld in HKSAR and Ma and Ors [1997] 2 HKC 315. The ultimate responsibility for the interpretation of the Basic Law lies under Art 158 with the Standing Committee of the National People's Congress: Y Ghai, "Sentinels of Liberty or Sheep in Woolf's Clothing? Judicial Politics and the Hong Kong Bill of Rights" (1997) 60 Modern Law Review 459; 459; Y Ghai, "Hong Kong and Macau in Transition - Debating Democracy”, Democratisation, Vol 2 No 3 [1995], 270.

${ }^{18}$ J Steyn "Human Rights: the Legacy of Mrs Roosevelt “ [2002] Public Law 473 at 483. Lord Steyn's comments on the peculiar office of the Lord Chancellor were noted in (2002) 76 Australian Law Journal 216. In July 2003 the office of Lord Chancellor was abolished, although later revived - temporarily it seems. Chief Justice Dixon pointed out that the strict application of the separation of powers was "artificial”, "impractical" and “opposed to British practice”: O Dixon “The Law and the Constitution” in Jesting Pilate 52. However, as a judge he was to give it strong and inconvenient application: eg The Queen v Kirby; Ex parte Boilermakers' Society of Australia (1956) 94 CLR 254.

191 Cranch (5 US) 137 (1803) discussed O Dixon “Aspects of Australian Federalism” in Jesting Pilate 113 at 115. 
When the functions of the High Court of Australia were being designed, it was assumed that the same power of authoritative disposition would devolve upon the court. However, to cure perceived defects in the United States arrangements, two important provisions were added to the Australian Constitution. Being constitutional grants of original jurisdiction, they could not be removed from the High Court by any action of the other branches of government. In s 75(iii) of the Australian Constitution it was provided that in all matters "in which the Commonwealth or a person suing or being sued on behalf of the Commonwealth is a party," the High Court would have original jurisdiction.

It has been argued that, inherent in the grant of such jurisdiction under $\mathrm{s}$ 75(iii) of the Australian Constitution was contained the power to make the jurisdiction effective, as by the issue of a writ of certiorari to quash a constitutionally invalid action of the Commonwealth or of a person being sued on behalf of the Commonwealth. ${ }^{20}$ In addition to this, to overcome a perceived gap of the United States Constitution identified in Marbury $v$ Madison, ${ }^{21}$ original jurisdiction was also granted to the High Court of Australia in all matters "in which a writ of Mandamus or prohibition or an injunction is sought against an officer of the Commonwealth.”

Although these paragraphs of the Australian Constitution, with their mention of particular remedies, including constitutional writs, represented an advance on the provisions of the United States Constitution, the fundamental idea concerning the function of the Judicature is one that has been adapted in Australia from the United States precedent. Needless to say, the assertion of such a large power of ultimate authority, and its acceptance by the people and government, provides a significant defence for constitutionalism. It represents an important check upon excess, or neglect, of jurisdiction. But it also assigns potentially controversial functions to the highest court. In Australia, as in the United States, the apex court is constantly called upon to arbitrate on the lawfulness of legislation as well as of executive and judicial acts purportedly done under authority derived from the Constitution.

\footnotetext{
${ }^{20}$ Australian Constitution, s 75(iii).

211 Cranch (5 US) 137 (1803) where it was held that Congress had exceeded its constitutional power by authorising the Supreme Court in its original jurisdiction to grant a writ of mandamus.
} 


\section{Common law courts:}

The High Court of Australia, like its United States counterpart, is a common law court. ${ }^{22}$ It uses common law techniques. It hears arguments in open court addressed to judges. They pronounce judgment in open court and publish reasons for their decisions. Those reasons are stated in the discursive manner of the common law, as distinct from the abbreviated and seemingly dogmatic fashion of most courts of civil law countries.

Precedent and the principle of stare decisis are important to both legal systems but they are not unchanging. Both courts are increasingly concerned with the meaning of legislation, a feature of an age in which the significance of judge-made law is being overtaken by written law enacted by legislatures. Yet even in the task of interpretation of legislation, there are principles of the common law that are observed for the ascertainment of the meaning of the legislation and the exposition of the operation of the law. The common law system avoids gaps in the law. If the Constitution is silent and there is no applicable legislation or rules made by the executive or the judges under delegated power, the judiciary in our tradition has the responsibility and function to state a rule of the common law apt for the case. This rule will be derived, for the most part, by analogical reasoning applied to earlier decisions so as to express a new rule that will fill the identified gap.

In the United States, the common law was received from England by the original colonies upon the theory, applicable also in Australia, that it was carried to the new territories as part of the inheritance of the English settlers. At the same time, the settlers brought with them the principles of equity. The persistence of these traditional streams of law was recognised in Article III of the United States Constitution with its reference to the jurisdiction of federal courts as including law (ie common law) equity and admiralty law. ${ }^{23}$. In Australia, the colonial courts were, like many of their predecessors in the American colonies, Royal Courts, established by royal decree or order in council made in the name of the King. Subsequently, specific legislation provided for the introduction of the common law into the several Australian colonies at a specified date. ${ }^{24}$ It was

\footnotetext{
${ }^{22}$ O Dixon "Two Constitutions Compared" in O Dixon Jesting Pilate (1997)100. ${ }^{23}$ US Constitution, Art III, s 2.

${ }^{24}$ A "Charter of Justice" dated 2 April 1787 purported to create courts of civil and criminal jurisdiction for the New South Wales colony. By a second set of Letters Patent on 4 February 1814, a "Supreme Court” and a "Governor's Court” were purportedly created. Because of doubts as to the validity of these instruments, the British Parliament enacted the Supreme Court Act 1823 (GB); 4 Geo IV c 96. This authorised new Letters Patent and the establishment of a Supreme Court as court of record providing the date for
} 
recognised that some rules of the common law might not be received into the new settlements, being unsuitable to the condition of those colonies at the time. However, in Australia, that exception was not generally given a broad operation.

Thus, as recently as 1978, the High Court of Australia held that the English rule that a convicted felon could not sue in the courts until he had served his sentence or received a pardon was suitable to the conditions of the Australian colonies and thus received as part of the common law of Australia. This was so although, at the outset of British settlement, a large proportion of the colonial population comprised convicted felons who would thereby be excluded from legal rights ${ }^{25}$. Similarly, the High Court held that the principle of English law relieving owners of cattle and sheep from liability for damage occasioned to others when their animals trespassed onto public highways, was not unsuitable to the condition of highways in Australia, different though they were. ${ }^{26}$ Such borderline decisions proved controversial. They attracted strong dissenting opinions in the High Court. ${ }^{27}$ But it is essential in any common law system to be able to identify the sources of the judge-made and statute law which later judges will be bound to apply. Where such law is inherited from another jurisdiction (as in the case of the United States and Australia) it is necessary to identify the date for the reception of that law so that disputes about the content of the inherited law will be diminished and can ultimately be resolved according to a clear principle.

Separation of judicial power:

Both the Supreme Court of the United States and the High Court of Australia are afforded constitutional guarantees of their independence from the other branches of government. So as are the other federal courts envisaged in Art III and Ch III of the two Constitutions. Section 71 of the Australian Constitution begins in language that is a direct copy of Art III sec 1 of the United States

the introduction of English law. There were similar developments in the other R P American Colonies: Meagher, W M C Gummow and J R F Lehane, Equity: Doctrines and Remedies (3rd ed) (Sydney Butterworths. 1992) 10-21.

${ }^{25}$ Dugan v Mirror Newspapers Ltd (1978) 142 CLR 583; cf US Constitution, Art III, s 3 forbidding "corruption of blood".

${ }^{26}$ State Government Insurance Commission v Trigwell (1979) 142 CLR 617; cf now Brodie v Liverpool Shire Council (2001) 206 CLR 512.

${ }^{27}$ In both Dugan and Trigwell Murphy J dissented: (1978) 142 CLR 583 at 606; (1979) 142 CLR 617 at 642. 
precedent. There is an additional reference in the Australian Constitution to the vesting of federal jurisdiction in "other courts." 28

The United States provision for the appointment of federal judges copied the statute of Great Britain expressly stating that the judges "shall hold their offices during good behaviour." 29 There is no exact equivalent in the Australian Constitution. There judicial tenure is implied from the express provision that Justices of the High Court and other federal courts shall not be removed except "on an address from both Houses of the Parliament in the same session praying for such removal on the ground of proved misbehaviour or incapacity". ${ }^{30}$ In the first century of the Australian Constitution no federal judge has been removed from office under this power. In one notable case, the power was invoked but the proceedings were later abandoned. ${ }^{31}$

\section{Jury trial: civil and criminal:}

The United States and Australian Constitutions inherited from the common law tradition of England the mode of jury trial that was common in that country at the time the two constitutions were written. In the United States and Australia jury trial continues to this day in serious criminal cases, both federal and State. The guarantee of jury trial contained in the United States Constitution ${ }^{32}$ influenced the terms of s80 of the Australian Constitution. The latter provision states that "The trial on indictment of any offence against any law of the Commonwealth shall be by jury, and every such trial shall be held in the State where the offence was committed, and if the offence was not committed within any State the trial shall be held at such place or places as the Parliament prescribes." The similarity to the United States text is obvious.

The significance of the Australian guarantee has been diminished by the strict interpretation applied to its language. In effect, the High Court of Australia has held that a precondition to the application of the constitutional guarantee is a

\footnotetext{
${ }^{28}$ Australian Constitution, s 71. See also s 77(iii).

${ }^{29}$ US Constitution, Art III, sec 1. The position in Great Britain was regulated by the Act of Settlement of 1701; 12 \& 13 Will III, c 2 and by the Commissions and Salaries of Judges Act 1760 (UK); 1 Geo III c 23.

${ }^{30}$ Australian Constitution, s 72(ii); cf US Constitution, Art 1 s 3 regulating articles of impeachment. Only one United States Justice has been subject to the impeachment procedure, namely Samuel Chase (1808). However, there were campaigns for the impeachment of Chief Justice Earl Warren and Justice William O Douglas. Justice Abe Fortas resigned in 1969, possibly in consequence of a threat of impeachment.

${ }^{31}$ The events concerning Justice L K Murphy is told in E Campbell and H P Lee, The Australian Judiciary (2001) 102-115.

${ }^{32}$ US Constitution, Art III, s 2.
} 
decision of the prosecutor to proceed with the criminal accusation against the accused federal offender "on indictment". ${ }^{33}$ If legislation authorises a summary procedure, and if that procedure is elected by the prosecutor, the result will be that the entitlement to jury trial will be bypassed. Along with other judges of the past, I have dissented from this construction of the guarantee of jury trial. ${ }^{34}$ There is no Australian equivalent to the 7th Amendment to the United States Constitution. In consequence, jury trial of civil causes has greatly declined in Australia in recent years. In most parts of Australia that mode of trial, if it still exists, is now confined to particular proceedings, such as actions for defamation or actions alleging fraud. ${ }^{35}$

\section{Dissenting opinions:}

A further important feature of the common law system is the right, enjoyed by appellate judges in the United States and Australia, to dissent if they disagree with the proposed orders or reasons of their colleagues. In both countries, this right is taken for granted. It is not common outside the common law world. On a visit to the Conseil Constitutionnel of France, I discovered not only that the right of dissent was not recognised but that very few of the members of the Council favoured its introduction. In part, this attitude originates in a different view about the nature of law. It may be affected by a culture that is fundamentally less libertarian than that of the common law. Or it might be traced to the traditions of the codifiers of the civil law whereby the law is ultimately to be found in an explicit provision whose clarity is a source of its legitimacy. In such societies, judicial elaboration of the law usually has a confined role. Indeed, it is often regarded as primitive, whereas we see it as honest and transparent.

Originally, the Judicial Committee of the Privy Council, to which appeals lay from Australia until their final abolition in $1986,{ }^{36}$ allowed no dissent. Formally,

${ }^{33}$ The King v Federal Court of Bankruptcy; Ex parte Lowenstein (1938) 59 CLR 556; Kingswell v The Queen (1985) 159 CLR 284; Cheatle v the Queen (1993) 177 CLR 541; Cheng $v$ The Queen (2000) 203 CLR 248.

${ }^{34}$ eg Cheng v The Queen (2000) 203 CLR 248 at 322-328 [220]-[237]. In my reasons I examined United States authorities such as Almendarez-Torres $v$ United States 523 US 224 (1998) and Appendi v New Jersey 68 USLW 4576 (2000). See ibid, 328-332 [238][351].

${ }^{35}$ Described in Naxakis v Western General Hospital (1999) 197 CLR 269 and Gerlach v Clifton Bricks Pty Ltd (2002) 209 CLR 478 and John Fairfax Publications v Rivkin [2003] HCA 50.

${ }^{36}$ Privy Council (Limitation of Appeals) Act 1968 (Aust); Privy Council (Appeals from the High Court) Act 1975 (Aust); Australia Act 1986 (Aust \& UK), s 11; Kirmani v 
this was justified because that court's reasons were expressed in the form of advice to the monarch. Conflicting advice was thought to be an embarrassment. Perhaps a somewhat similar view lies behind the civil law tradition that excludes dissents. Disagreements are thought to cast doubt on the authority of the court pronouncing its judgment and uncertainty about the content of the resulting law. As in the Privy Council, this attitude inevitably leads to judicial reasons that are often the product of compromise, as attempts are made to include sometimes incompatible opinions in the one text. Some reasons of the European Court of Justice (which permits no dissents) appear to reflect a similar internal tension. The European Court of Human Rights (whose judges enjoy the right of dissent) avoids such problems. So do the appellate courts of Australia and the United States. From the start after the English tradition, judges have, in both countries, always been entitled, indeed obliged, to express their true opinions either as to the outcome of a case or, if agreeing in the outcome, as to the reasons that support the order or judgment disposing of the matter.

Both in Australia as in the United States, only a minority of decisions of the highest court are unanimous. Dissenting and separate concurring opinions are a regular feature of the work of each final court. Their existence is accepted as reflecting the difficulty and controversy of the cases that come before such courts. They may also reflect the fairly consistent inclinations that emerge in the responses of individual judges, and groups of judges, to the resolution of legal contests. This is so in the United States Supreme Court. It is also true in my Court.

In the early days of each court, in part because of the commanding influence respectively of Chief Justice Marshall and of Chief Justice Griffith, there were relatively few dissents. Each of the original Justices of the High Court of Australia (Griffith, Barton and O'Connor) had played an active part in framing the Australian Constitution. They shared common views about its meaning and essential purposes. In the first four years of the High Court, there were only four dissenting opinions, all of them by Justice O'Connor. None was on a constitutional question. But this unanimity broke down with the appointment in 1906 of Justices Isaacs and Higgins, the former especially being of a different opinion on many constitutional and legal questions to that of the founding Justices. The unanimity of the first years has never been recaptured.

In Australia, as in the United States, dissenting opinions can sometimes influence later judicial decisions. Occasionally this happens after a relatively

Captain Cook Cruises Pty Ltd [No 2]; Ex parte Attorney-General (Qld) (1985) 159 CLR 461 at 464 . 
short time. ${ }^{37}$ Sometimes it occurs after many decades. ${ }^{38}$ Some judges dissent rarely. In recent years I have dissented in about $30 \%$ of the matters decided by the High Court. That is the highest proportion in the history of the High Court. The previous highest rate of dissent was by Justice Lionel Murphy (about 20\%). ${ }^{39}$ The next highest amongst the current Justices is Justice McHugh (15\%), after which the level trickles away to insignificant numbers. However, the right of dissent belongs to every Justice. Attitudes to its use differ. It is a precious feature of the exercise of the judicial power in both countries.

The judicial life:

The daily work of the Justices of both courts is quite similar. Much time is spent in reading written casebooks and argument. Time is also spent reviewing the written material filed on behalf of those who seek to engage the jurisdiction of the Court. In the early days of each Court, after the English tradition, most of the work was performed by the judges sitting in open court, listening to argument and sometimes disposing of decisions by ex tempore opinions and the pronouncement of orders and judgments at the end of the hearing. In more recent times, the oral trial tradition has declined in both courts, although oral argument in open court remains a central feature of the methodology of each body.

In the United States, the Supreme Court, serving a much larger and even more litigious society, has long required written procedures for the admission of cases to the Court's docket. In Australia, a provision governing rights of appeal to the High Court in civil matters (determined by reference to the value of the matter at stake) persisted until 1984. Federal legislation then empowered the High Court to control its own appellate jurisdiction. Today, virtually universally, that jurisdiction is subject to the requirement of special leave to appeal granted by the Court. ${ }^{40}$ In this way, each court now selects the cases it will determine.

Applicants for special leave to appeal in Australia are normally allowed twenty minutes in which to advance oral arguments the substance of which has

${ }^{37}$ eg Dietrich v The Queen (1992) 177 CLR 292 overruled McInnes v The Queen (1979) 143 CLR 575; Re Wakim; Ex parte McNally (1999) 198 CLR 511 overruled Gould v Brown (1998) 193 CLR 346.

${ }^{38}$ Tame $v$ New South Wales (2002) 76 ALJR 1348; 191 ALR 449 overruled in part Chester v Waverley Corporation (1939) 62 CLR 1; Re Patterson; Ex parte Taylor (2001) 207 CLR 391 overruled Nolan v Minister for Immigration and Ethnic Affairs (1998) 165 CLR 178.

39 J Hocking Lionel Murphy: A Political Biography (2nd ed) (Cambridge, Cambridge University Press, 2001).

40 Judiciary Act 1903 (Aust), s 35 upheld in Carson v John Fairfax and Sons Ltd (1991) 173 CLR 194. 
already been considered by the Justices in the parties' written submissions. The workload imposed by these proceedings has led to suggestions either that a universal system of written application should be substituted, as in the United States Supreme Court, or that the High Court should itself decide whether oral argument would be of help to it. The conduct of oral argument in matters of constitutional and legal significance not only has utility for the Justices in allowing them to clarify key questions. It also has a strong symbolic significance. If all argument is in writing the transparency of the judicial process is to that extent diminished. Oral hearings, even in the final court, continue to have many supporters in Australia. The time for an oral hearing of an appeal, once special leave is granted, or of a proceeding in the original jurisdiction of the High Court, is not limited to 20 minutes. The Court assigns the date for the hearing. Normally, it leaves it to the parties to allocate the assigned time between themselves. Oral argument is thus more extensive than is usual in the United States court.

The role of clerks:

The Justices today in both courts enjoy assistance not only from the written briefs and the advocacy of the parties and interveners. They also engage young law graduates appointed for a short period to work in the Justices' chambers. In Australia, these clerks are called "associates". The Justices of the High Court each have two such associates. Appointment to such positions is highly sought after. In my own case I advertise vacancies each year in all Australian law schools. In consequence, I receive hundreds of applications. Eventually these are reduced to one male and one female appointee. I do not chose my staff from particular law schools or on the nomination of others, as seems to be a common tradition in the United States. On the contrary, I observe strict equal opportunity principles in their recruitment. Each Justice in Australia has his or her own system of making such appointments. So far, two former associates have been appointed Justices of the Court - Justice McTiernan (who was associate to Justice Rich) and Justice Aitkin (who was associate to Chief Justice Dixon).

The world of ideas:

Most Justices in both countries today accept responsibilities outside the courtroom. They participate in professional, academic and other functions in keeping with the educative role of a judge of a final court. Not all Justices welcome such obligations; although some do. In the Commonwealth of Nations, there is an Association of Commonwealth Judges and Magistrates that holds regular conferences at which they can share judicial experiences. Commonwealth Law Conferences and specialist meetings of Commonwealth 
judges provide opportunities for comparing notes on the common issues facing national final courts of appeal. Judges of such courts are also expected to take part in the meetings of judges of their own country where, necessarily, they play a leadership role beyond the pages of the court reports.

Beyond the nation and such Commonwealth meetings, there is an increased tendency in recent years to bring together judges from a wider range of countries, including those from other countries of the common law and civil law traditions. For example, a global constitutionalism seminar is held every year at the Yale Law School. I have attended that series in recent years together with Justice Breyer of the Supreme Court of the United States, Lord Chief Justice Woolf of the United Kingdom, Justice Iacobucci of the Supreme Court of Canada and judges from the supreme courts of countries as diverse as Hong Kong, India, Israel, Japan, Peru, Poland, the European Court of Human Rights and the French Conseil Constitutionnel.

In such meetings judges of final courts quickly recognise the commonality of questions that arise for decision prompted by the same or similar social movements. Acknowledging fully the duty of obedience to their own constitutions and laws, knowledge about contemporaneous approaches to common problems can sometimes enhance the quality of local judicial solutions. At a number of international seminars attended by Justices of the Supreme Court of the United States, I have participated, as they have, in discussion of the growing influence of international human rights norms upon domestic judicial decision-making. ${ }^{41}$

The recent references in the majority opinions in Virginia $v$ Atkins ${ }^{42}$ and Lawrence $v$ Texas $^{43}$ to international developments relevant to the issue in hand suggest that the United States Supreme Court is now joining other final courts in using this source of legal reasoning. Atkins concerned the carrying into effect of a sentence of death upon a mentally handicapped prisoner. Lawrence concerned the constitutional validity of the Texas anti-sodomy laws. Jurisdiction can occasionally be an intellectual prison for a judge. Of course, some are content to live out their days in that prison, regarding it as their only proper place. However, in the age of jumbo jets, the Internet and much greater trans-border judicial dialogue, it is now possible for judges of the High Court of Australia, the Supreme Court of the United States and other final courts to meet, as they regularly do. Globalism is not only a feature of the modern economy. It is a

${ }^{41}$ M D Kirby “The Australian use of International Human Rights Norms: From Bangalore to Balliol - A View from the Antipodes” (1993) 16 University of NSW Law Journal 363.

42536 US 304 at 329 (2003), (fn 21) Opinion of the Court per Stevens J.

4371 USLW 457 at 4578-4580 (2003). Opinion of Kennedy J for the Court. 
vehicle for the development of ideas. Legal ideas are an important category that are not immune from this development.

Robes, salaries and taxes:

There are some minor and relatively trivial similarities between the two courts. The robes of the Justices are now very similar. Until 1986, the Justices of the High Court of Australia wore the traditional robes of the English judiciary. This meant that, when sitting in a hearing, they wore a wig, an accoutrement to which all of them were long accustomed when practising as barristers. Now, in the High Court, my robes represent an even more austere copy of those worn in Washington.

Another similarity exists in the relative decline in the remuneration of Justices both in the United States and in Australia. In 2002 Chief Justice Rehnquist and Justice Breyer drew this decline to the notice of Congress and the American public. ${ }^{44}$ Similar complaints have been made on behalf of the Australian judiciary. The remuneration of the Justices of each Court is protected by a "compensation clause". The Australian provision was modelled directly on that of the United States. ${ }^{45}$ As in the United States, the problem has not been one of actual diminution of remuneration (save for a suggestion by the Australian government during the Great Depression that the Justices of the High Court should accept a reduction in their emoluments in common with other federal office-holders). ${ }^{46}$ The real source of complaint is the comparative decline of judicial salaries when compared to those paid to the justices at the foundation of the Court; in comparison with other officials and wage earners at that time; and in comparison with the incomes of the practising legal profession. As in the United States, ${ }^{47}$ the view has generally been taken in Australia ${ }^{48}$ that nondiscriminatory taxation upon federal judges does not conflict with the prohibition upon the reduction of salaries and other benefits enjoyed by Justices already appointed to office. However, in a recent case, the High Court of Australia struck down a federal taxation law directed at the pension benefits of newly

44 Statement of W H Rehnquist, Chief Justice of the United States, before the US National Commission on the Public Service, 15 July 2002.

45 Australian Constitution, s 72(iii).

46 J Bennett Keystone of the Federal Arch (1980) 46. (The Boyer Lectures, Radio National December 17, 1980).

${ }^{47}$ United States v Hatter 532 US 557 (2001).

${ }^{48}$ Cooper v Commissioner of Income Tax (Q) (1907) 4 CLR 1304. 
appointed State judges, holding that the federal law impermissibly interfered in the government of the State preserved by the federal Constitution. ${ }^{49}$

Apart from these commonalities, daily life is similar. In a final court there is no relief from the obligations of reading, research, decision-writing, amendment of drafts, checking of proofs of opinions and discussion of the product with one's colleagues and staff. The business of running a court within an assigned budget falls heavily on the Justices, aided by court staff. The work of both courts is mentally taxing and unremitting. But it is also intellectually exhilarating. Within the law, there are few posts that offer the same cerebral rewards as a seat on the final court of one's nation. In the nature of things, few individuals attain such an office. Many lawyers of great ability miss out, by chance or politics or because of factors over which they have no control. In the history of the United States, 105 persons have been appointed to the Supreme Court including the nine present incumbents. In Australia, over the course of a century, 44 Justices have been appointed. The responsibilities are accepted freely with a cheerful heart because nobody is obliged to remain in such an office a day longer than he or she wishes. Always waiting in the wings are aspirants, many of them worthy.

\section{DIFFERENCES}

In spite of these similarities, there are significant differences between the roles which the final courts play in the United States and Australia and the functions of the Justices within those courts.

\section{Appointment and qualifications:}

The coming into office is quite different. By the United States Constitution, the President has the power to appoint judges of the Supreme Court and all other officers of the United States not otherwise provided for in the Constitution. However, the President may only do so with the advice and consent of the Senate. ${ }^{50}$ There is no similar control upon the appointment of judges by the Executive Government in Australia.

No Australian judicial officer is elected. All are appointed with tenure and independence by the Executive Government of their jurisdiction - federal, State or Territory. Although the Australian Senate is one House of the Federal Parliament, ${ }^{51}$ that body has no part to play in the appointment of judges. The only parliamentary power with respect to judges is to consider a prayer for

\footnotetext{
49 Austin v The Commonwealth (2002) 77 ALJR 491; 195 ALR 321.

${ }^{50}$ US Constitution, Art I, s 2.

${ }^{51}$ Australian Constitution, s 7.
} 
removal and then only on the specified grounds and conditions and within a specified time. ${ }^{52}$ In the matter of appointments, the Executive is untrammelled. By the Constitution, appointments to the High Court are made by "the GovernorGeneral in council." 53 The Governor-General is the Queen's representative in Australia. The council referred to is the Federal Executive Council. ${ }^{54}$ Historically, this is a copy of the Queen's Privy Council in the United Kingdom. But by the Australian Constitution, it is made up exclusively of Ministers of the Australian Government, together with the Governor-General. The GovernorGeneral has powers - substantially to be consulted, to encourage and to warn. Like the Queen he must, by convention, normally accept the advice of the Ministers expressed in the Executive Council.

There are legal requirements relating to the qualifications for office as a Justice of the High Court. ${ }^{55}$ However, these hardly reflect the conventional qualifications that are normal for such appointments. Usually these are long and high judicial service, experience as a leading barrister or, more rarely, political service. Recently, provision has been made in Australia by which the federal Attorney-General, before an appointment of a new Chief Justice of the High Court or Justice, is obliged to consult the States about such appointments. In Australia, unlike India, ${ }^{56}$ this statutory obligation of "consultation" means no more than that. There is no obligation to appoint anyone whom the States nominate. The most that the statutory procedure of consultation achieves is to identify some leading candidates for appointment. The entire process takes place behind closed doors.

Inescapably and naturally, there is a high degree of political involvement on the part of the Federal Cabinet and Government of the day when a vacancy on the High Court of Australia falls to be filled. There are no confirmation hearings. Indeed, there is no public process at all. There is not even a process of advertisement and formal interview, as is now more common with other judicial appointments in Australia. After the recommendation of the Federal Cabinet has been conveyed to the Governor-General (and sometimes even before) the announcement is made by the Prime Minister or the Federal Attorney-General. And that is it.

Despite the apparent success and general acceptance of the procedures for public interview for judicial appointments and promotions in South Africa under

\footnotetext{
${ }^{52}$ Australian Constitution, s 72(ii).

53 Australian Constitution, s 72(i).

54 Australian Constitution, s 63.

${ }^{55}$ High Court of Australia Act 1979 (Aust), s 6.

56 Supreme Court Advocates' Association v Union of India [1994] AIRSC 268; [1993] Supp 2 SCR 659; Special Reference No 1 of 1998 JT 1998 (5) SC.
} 
the post-apartheid Constitution, few judges or politicians in Australia would favour the introduction of a confirmation process similar to that of the United States. None could be found who would support the system of elected judges, a method of judicial appointment (and removal) apparently difficult to reconcile with true judicial independence. ${ }^{57}$ The theoretical imperfections of the present system of judicial appointments in Australia are raised each time an important appointment is made. And then, the institution closes around the new appointee. He or she gets on with the work. The political process turns to other things. It is rare that this system delivers an inadequate or incompetent appointee. Inevitably, governments hope that their appointees will reflect, in a general way, their philosophical viewpoint. They are often disappointed. But this is so both in the United States and in Australia.

\section{Fixed retirement:}

Once appointed, a Justice of the High Court of Australia serves to the age of seventy years unless earlier retiring from, or dying, in office. Originally, the Australian Constitution contained no maximum term of appointment. Following the United States precedent it did not take long for the High Court to hold that the constitutional silence meant that appointees held office for life. ${ }^{58}$ This is one of the reasons for the small number of office-holders in both courts.

In the early 1970s, in the absence of Chief Justice Barwick, the Senior Justice, Sir Edward McTiernan, went to the Parliament to administer the oaths of office to the new members. Many of the parliamentarians were so shocked at his advanced age (he was then in his eighties) that moves arose to amend the Australian Constitution to provide for a compulsory retirement age. The Constitutional Alteration (Retirement of Judges) proposal was enacted by the Federal Parliament in 1977. The amendment was then approved by the electors. It attracted the dual majorities required to effect a change of the Australian Constitution. ${ }^{59}$ The amendment did not affect the tenure of serving Justices.

Although there is a handful of "lifers" on the federal Family Court of Australia, life tenure has now all but disappeared from the Australian judicial

\footnotetext{
${ }^{57}$ International Covenant on Civil and Political Rights, Art 14.1.

${ }^{58}$ In Waterside Workers' Federation of Australia v J W Alexander Ltd (1918) 25 CLR 434.

59 The Australian Constitution, s 128 requires that, to be effective, an amendment of the Constitution must be adopted by the Federal Parliament and approved by a majority of the electors nationwide and in a majority of the States. The proposal to introduce retirement ages for the federal judiciary was approved on 21 May 1977. The nationwide affirmative vote was $78.63 \%$. The amendment was carried in every State.
} 
scene as federal judges appointed before 1976 died or retired from office. In most Australian States, for many years, judicial tenure was to the age of seventy or seventy-two. Few Australians, including few judges, are mourners for the passing of life tenure. Although some very distinguished judges of the past would have been lost in Australia by compulsory retirement, the Constitution serves contemporary society. The regular appointment of younger people to a nation's supreme court is a means of injecting new approaches and new ideas, permitting regular change at the nomination of elected governments and avoiding the spectacle of very old judges serving on beyond their prime or in the hope of holding out until a change of administration.

\section{A general appellate court:}

The High Court of Australia is a general court of appeal. It hears appeals from judgments and orders of virtually all Australian courts - State, Federal and Territory. In this sense, it brings together the entire Australian legal system. The work of its Justices is not confined to the application of federal law. They decide appeals on purely State law matters having nothing to do with the Constitution or federal legislation.

This feature of the High Court - which it shares with the Supreme Courts of Canada and India - has two important consequences. First, it places the High Court in the mainstream of the general judicial system. It marks the Court out as a general court of ordinary law. This means that constitutional and federal questions are typically perceived as an aspect of the law, not as something divorced and different. Secondly, this character affects the qualifications essential to perform the functions of a High Court Justice successfully. It affects the appointees' self-image. It rubs off on their conception of their own function. ${ }^{60}$ There is nothing like a few days deciding abstruse questions of State statutory law to bring a constitutional philosopher down to earth.

Other countries (such as South Africa) have followed the European tradition and established a separate constitutional court, with judges appointed for fixed terms. However, the Australian court is a court of law in the fullest sense. Its role in supervising decisions of State courts is assured by two constitutional provisions. The first is the entrenched power to hear appeals from judgments and orders of the Supreme Courts of the States and from any other State court from which, at the establishment of the Commonwealth, an appeal lay to the Privy Council. ${ }^{61}$ As well, a novel provision in the Australian Constitution permitted

${ }^{60}$ O Dixon “Two Constitutions Compared” in Jesting Pilate 100 at 104.

${ }^{61}$ Australian Constitution, s 73(ii). 
the Federal Parliament to invest any court of a State with federal jurisdiction. ${ }^{62}$ This very important power was quickly utilised by the passage of the Judiciary Act 1903 (Aust). ${ }^{63}$ The growth of federal courts, other than the High Court itself, did not take place in Australia to any degree until the 1970s when the Family Court of Australia ${ }^{64}$ and the Federal Court of Australia ${ }^{65}$ were established. More recently, the Federal Magistrates Court has been created. ${ }^{66}$ The investing of other courts with federal jurisdiction has been a very successful constitutional idea. It too has reinforced the integration of the nation's Judicature.

When a State Parliament endeavoured to impose duties on a State Supreme Court that were challenged as inimical to the exercise of judicial power, the High Court of Australia found the State law invalid. It held that the Australian Constitution not only protected the independence of federal courts but, because of the inter-relationship of federal and State courts, it also protected the independence of the latter. As it was put, the State courts were required to be suitable receptacles for the exercise of the federal jurisdiction provided by the Constitution. ${ }^{67}$ This was a case of deriving inferences from the Constitution, a process that has occurred in Australia throughout the history of federation. ${ }^{68}$

At the time of federation in Australia, the colonial courts were already long established. There were well respected and subject to appeal to the Privy Council. The evenness of their quality was one of the reasons for the delay in the establishment in Australia of a substantial and separate federal judiciary. ${ }^{69}$ When, eventually, significant federal courts were created to deal with particular aspects of federal jurisdiction deemed specially appropriate for national administration, those courts, in turn, became part of the integrated judiciary that comes together in the High Court. In a sense, the facilities of appeal and the vesting of jurisdiction have strengthened the unity and integration of the Australian Judicature. They have upheld the generally uniform standards of appointment and performance of judicial officers in all Australian courts.

\footnotetext{
${ }^{62}$ Australian Constitution, s 77(iii).

63 Judiciary Act 1903 (Aust) ss 39, 39A, 64, 68, 79, 80.

${ }^{64}$ Family Law Act 1975 (Aust), s 21.

${ }^{65}$ Federal Court of Australia Act 1976 (Aust), s 5.

${ }^{66}$ Federal Magistrates Act 1999 (Aust).

${ }^{67}$ Kable v Director of Public Prosecutions (NSW) (1996) 189 CLR 51.

${ }^{68}$ eg Lange v Australian Broadcasting Corporation (1997) 189 CLR 520.

${ }^{69}$ Re Wakim; ex parte McNally (1999) 198 CLR 511 at 605 [200].
} 


\section{A national common law:}

In consequence of this judicial integration, Australia has rejected the notion of a separate federal common law or separate systems of common law for each of the polities making up the federation. Instead, the High Court has held that there is a single, uniform common law applicable throughout the nation. Ultimately, it is susceptible to ascertainment and exposition by the High Court itself. ${ }^{70}$ The notion of a single Australian common law, modified by local State and Territory legislation, involves some theoretical difficulties. ${ }^{71}$ In the United States, each State has its own common law as expounded by its own courts. ${ }^{72}$ The Australian insistence upon a single body of the common law has been strongly affirmed in recent decisions of the High Court. ${ }^{73}$ The constitutional foundation for this doctrine lies in the unifying role of the High Court as the sole final court of appeal of Australia.

\section{The Commonwealth connection:}

That function of the High Court as the final appellate court is comparatively recent. At the outset of federation, appeals lay to the Privy Council in London both from the High Court of Australia itself and from State supreme courts. The larger facility for Privy Council appeals was one of the few amendments upon which the British Government insisted when it was presented with the Constitution drafted by the Australian Constitutional Conventions of the 1890s. There were two derogations from the Privy Council's jurisdiction envisaged by the Constitution. The first, demanded by the colonists, was that appeal would only lie to the Privy Council on constitutional questions as to the respective powers of the Commonwealth and the States if a certificate to allow such an

\footnotetext{
${ }^{70} R$ v Kidman (1915) 20 CLR 425. Lange v Australian Broadcasting Corporation (1997) 189 CLR 520. Indeed, earlier it was commonly stated that there was but one common law applicable throughout the entire British Empire as pronounced by the courts of England: cf O Dixon “Two Constitutions Compared” in Jesting Pilate 100 at 104-105.

${ }^{71}$ L J Priestley, “A Federal Common Law in Australia?” (1995) 6 Public Law Review 221.

${ }^{72}$ Erie Railroad Coal v Tompkins 304 US 64 (1938).

${ }^{73}$ Lipohar $v$ The Queen (1999) 200 CLR 485; John Pfeiffer and Son Pty Ltd v Robertson (2000) 203 CLR 503; Regie Nationale des Usines Renault SA v Xhang (2002) 76 ALJR 551; 187 ALR 1.
} 
appeal was granted by the High Court. ${ }^{74}$ In the history of federation, only one such certificate was ever granted. ${ }^{75}$ Many were refused.

As well, provision was included in the Australian Constitution for the Federal Parliament to make laws "limiting matters in which" leave to appeal to the Privy Council might be granted. ${ }^{76}$ Eventually, appeals from the High Court and federal courts were "limited" under this provision to the extent of abolition. ${ }^{77}$ The validity of such "limitation" was upheld. ${ }^{78}$ In due course, the direct appeals from the State supreme courts were also abolished. ${ }^{79}$ This was done by concurrent legislation of the Australian federal and State Parliaments and the United Kingdom Parliament. The laws were symbolically given the Royal assent by the Queen personally during a visit to Canberra. Normally such assent is given by the Governor-General or Governor in the Queen's name.

There is now no external or higher court for Australian judicial decisions beyond the High Court of Australia. Inevitably, this change in the function of the High Court from one subordinate in most matters to the Privy Council to a court of final appeal has brought the High Court closer to a perception of its functions similar to that of the Supreme Court of the United States. Having myself sat both in a final appellate court and one subject to further appeal, I know the difference. The change in status of the High Court was quickly followed by a period of significant creativity on the part of the Court during the years in which Chief Justice Mason presided. $^{80}$ If, in more recent years, the creativity of the Court has diminished, this is no more than a normal feature of the way common law courts tend to operate in fits and starts, rather than at a uniformly steady pace.

Given the character of other final appellate courts throughout the world, it seems unlikely that the High Court of Australia will, in the long term, revert to the rather limited view of its functions held by Australian judges and lawyers during the time when the court was subject to Privy Council supervision. Whilst some lawyers in Australia still hanker for a return to those "good old days", the example of the Supreme Court of the United States indicates the necessity and inevitability of the creative function of an ultimate court of a nation having

\footnotetext{
${ }^{74}$ Australian Constitution, s 74.

${ }^{75}$ Deacon v Webb (1904) 1 CLR 585; Baxter v The Commonwealth (1907) 4 CLR 1178. The only certificate ever granted was in Attorney General (Commonwealth) $v$ Colonial Sugar Refining Co Ltd [1914] AC 237; 17 CLR 644.

76 A R Blackshield "The Abolition of Privy Council Appeals” in A R Blackshield and G Williams, Australian Constitutional Law and Theory (3rd ed, 2002), 570.

${ }^{77}$ By legislation culminating in the Australia Acts 1986 (Aust)(UK), s 11.

${ }^{78}$ Kirmani v Captain Cook Cruises Pty Ltd [No 2] (1985) 159 CLR 461 at 464.

${ }^{79}$ Australia Act 1968 (Aust) (UK), s 11.

${ }^{80}$ Sir Anthony Mason was Chief Justice of Australia from 1987 to 1995.
} 
constitutional responsibilities. ${ }^{81}$ Such creativity, harnessed to legal authority, is the essential characteristic of all common law courts. Those who dispute this fact must explain where the great body of the common law came from if not from judicial invention.

On the whole, the link of the High Court of Australia to the Privy Council was not an onerous burden on the Court's judicial performance. In colonial days especially that link saved the Australian legal system from parochialism that might otherwise have afflicted it. ${ }^{82}$ By affording the facility of appeal in a small number of cases to the judges of England who sat in the Privy Council, that body provided a wealth of comparative law doctrine, largely drawn from English court decisions, that greatly enriched Australian law.

Now, Australian courts are not bound by any foreign judicial decision. For the moment, Australian courts observe Privy Council decisions given in Australian appeals during the time when that Court was part of the Australian judicial hierarchy. ${ }^{83}$ Yet the termination of this last formal link has brought an even greater flowering of comparative law material into the Australian courts. It is now extremely rare for the High Court of Australia to decide any major issue of constitutional or common law without examining the way in which similar issues have been dealt with in other like common law countries, particularly the United Kingdom, the United States and Canada.

On the other hand, an examination of United States decisions indicates the contrast that exists in the higher English, Canadian, New Zealand, South African, Indian and other courts of the Commonwealth of Nations where there is a much greater inclination to look outwards for analogies and reasoning. Such sources frequently prove of great advantage to the performance of the judicial task. In the United States, there are more than fifty home jurisdictions. They serve a single nation. But in the post-Imperial world of Commonwealth countries, it is a great strength of the common law technique, as now practised, that judges are accustomed to, and comfortable with, the citation of judicial opinions, written in the same language, tackling similar questions in different countries. Parochialism is a common problem for lawyers. It is reinforced by jurisdictionalism which is an inescapable aspect of lawyering. The contemporary common law affords a treasure house of readily available analogies. These are now available through the Internet. They greatly enrich judicial performance in countries such as my own.

${ }^{81} \mathrm{H}$ Luntz "Throwing off the Chains: English Precedent and the Law of Torts in Australia” in M P Ellinghaus \& Ors The Emergence of Australian Law (1989), 70.

${ }^{82}$ F C Hutley "The Legal Traditions of Australia Contrasted With Those of the United States” (1981) 55 Australian Law Journal 63 at 68.

${ }^{83}$ Cook v Cook (1986) 162 CLR 376 at 390. 


\section{Absence of a Bill of Rights:}

The Australian Constitution does not include a general bill of rights. The founders of the Commonwealth shared James Madison's initial opinion that it was impossible to define the rights of the people. It is not true to say that the Australian Constitution contains no rights provisions. However, they are limited. As in the case of the right of jury trial, they have sometimes been the subject of restricted interpretations. ${ }^{84}$

Most modern constitutions contain charters of fundamental rights. Where they do not, statements of rights have frequently been added. Thus, the Canadian Charter of Rights and Freedoms was adopted in $1982 .{ }^{85}$ Even in the United Kingdom, for half a century, the law has been subject to scrutiny in accordance with the European Convention on Human Rights. ${ }^{86}$ Since 2000, the Human Rights Act 1998 (UK) has rendered many human rights issues justiciable in the courts of Britain. Australia is one of the last civilised nations not to have such a charter. The conventional source of the opposition, particularly amongst politicians, is that bills of rights introduce needless inflexibility into law-making and enhance judicial power at the expense of democratic accountability.

The absence of a general bill of rights does not mean that the High Court of Australia is totally incapable of defending basic civil liberties when they are threatened by intrusive legislation or governmental action. Sometimes, express provisions of the Constitution have been enlisted to strike down federal legislation affecting the compulsory acquisition of private property ${ }^{87}$. Sometimes federal legislation is found invalid, as was the attempt to dissolve the Australian Communist Party in 1950. That law failed for want of an appropriate foundation in federal legislative power. ${ }^{88}$ The decision of the High Court of Australia in that

${ }^{84}$ Kingswell $v$ The Queen (1985) 159 CLR 264. There has been a similarly narrow reading of s 116 of the Australian Constitution concerning freedom of religion: AttorneyGeneral (Vict); Ex rel Black v The Commonwealth (1981) 146 CLR 559.

${ }^{85}$ The Canadian Charter was preceded by the Canadian Bill of Rights 1960 (Can). See M R Wilcox An Australian Charter of Rights? (1993) 28-36.

${ }^{86}$ See eg Dudgeon v United Kingdom (1981) 4 EHRR 149; (1983) 5 EHRR 573. For a description of the different ways in which issues of rights are addressed in the two legal systems see M D Kirby, "Law and Sexuality: The Contrasting Case of Australia" 12 Stanford Law \& Policy Review 103 (2001).

87 Bank of New South Wales v The Commonwealth (1948) 76 CLR 1 ("Bank Nationalisation Case”).

${ }^{88}$ Australian Communist Party v The Commonwealth (1951) 83 CLR 1. This may be contrasted with Ex parte Quirin 317 US 1 (1942) upholding trial of alleged saboteurs in wartime by a military commission not the civilian courts. See G E White, "Felix

Footnote continues 
case stands in marked contrast to the contemporary decision of the Supreme Court of the United States involving the constitutional validity of similar provisions contained in the Smith Act. Despite the express guarantees of freedom of speech and freedom of association in the United States Constitution, ${ }^{89}$ the Supreme Court of the United States, by majority, upheld the severe civil restrictions imposed by Congress on communists. ${ }^{90}$ This ironic outcome of two constitutional challenges demonstrates that liberty sometimes depends upon more than constitutional texts.

\section{Constitutional implications:}

In recent times, the High Court of Australia has found implications of rights in the constitutional text, including of an irreducible freedom in certain circumstances to discuss matters of politics and government. ${ }^{91}$ This lastmentioned freedom was found to be implied in the representative electoral democracy established by the Australian Constitution. ${ }^{92}$ Without such a freedom, it was held, the democratic elements of the Constitution would be defeated or reduced to a charade. Other cases have suggested that an inference should be derived from the independent Judicature established by the Constitution to support an implied constitutional guarantee of due process of law $^{93}$ and of unbiased judges. ${ }^{94}$ These insights have not yet won a majority amongst the present Justices.

Apart from the constitutional guarantees, liberty is protected in Australia by the strong presumption that legislation does not reduce fundamental civil rights,

Frankfurter's Soliloquy in Ex parte Quirin”, 5 Green Bag (2nd Series), 423 (2002); cf Lloyd v Wallach (1915) 20 CLR 299.

${ }^{89}$ US Constitution, First Amendment.

${ }^{90}$ Dennis v United States 341 US 494 (1951).

${ }^{91}$ Nationwide News Pty Ltd v Wills (1992) 177 CLR 1; Australian Capital Television Pty Ltd $v$ The Commonwealth (1992) 177 CLR 106; Theophanous $v$ Herald and Weekly Times Ltd (1994) 182 CLR 104.

${ }^{92}$ Lange v Australian Broadcasting Corporation (1997) 189 CLR 520.

${ }^{93}$ Polyukovich v The Queen (1991) 172 CLR 501 at 607-612, 703, cf 532, 689; Leith v The Commonwealth (1992) 174 CLR 455 at 484-488, 501-502; cf at 466-469; see Parker, "Protection of Judicial Processes and Implied Constitutional Principles" (1994) 16 Adelaide Law Review 341.

${ }^{94}$ Ebner v Official Trustee (2001) 205 CLR 337 at 363 [81]-[82]; 362-373 [114]-[117]; cf Tumey v Ohio 272 US 510 (1927). 
unless such a purpose is clearly and unmistakenly expressed in valid legislation. ${ }^{95}$

Australia does not have the same constitutional protections for free expression as exist under the First Amendment, as interpreted by the Supreme Court of the United States. ${ }^{96}$ However, this is, in part, due to a different balance that has been struck by legislation (and by the common law) between free speech values and values protective of other important attributes of human dignity such as honour, reputation and privacy. These competing values also appear in international human rights instruments. ${ }^{97}$ They represent human rights deserving legal protection as much as the human right to free expression. Most Australians, and most Australian judges (although not the Australian media) consider that the balance struck by United States judicial authority on this subject is somewhat extreme. $^{98}$ The interface between the United States approach and that of Australian law has come to the fore in recent decision of the High Court of Australia concerning a publication about an Australian citizen uploaded on the Internet in the United States but downloaded to do its principal damage and hurt to reputation in Australia, where the plaintiff lived. ${ }^{99}$

The absence of a formal bill of rights in the Australian Constitution has tended to reinforce the view that most of the High Court Justices have held about their role. It has tended to emphasise legalism and to diminish a creative and adaptive spirit that usually accompanies judicial interpretation of the language of a constitutional bill of rights. Although there are sporadic suggestions that Australia should adopt a constitutional bill of rights, ${ }^{100}$ an attempt to include basic rights in the federal Constitution was overwhelmingly rejected in a constitutional referendum held in 1988. ${ }^{101}$ Given the Australian record on

${ }^{95}$ Bropho $v$ Western Australia (1990) 171 CLR 1 at 20; Durham Holdings Pty Ltd $v$ New South Wales (2001) 205 CLR 399 at 414-415 [27]-[31]; The Daniels Corporation International Pty Ltd v Australian Competition and Consumer Commission (2002) 77 ALJR 40; 192 ALR 561.

${ }^{96}$ eg New York Times Co v Sullivan 376 US 254 (1964); Rosfenbloom v Metromedia 403 US 29 (1971); Gertz v Robert Welch, Inc 418 US 323 (1974).

${ }^{97}$ eg International Covenant on Civil and Political Rights, Arts 17 (privacy, honour and reputation), 19 (freedom of opinion and expression).

98 Australian Broadcasting Corporation v Lenah Game Meats Pty Ltd (2002) 208 CLR 199 at 282-283 [199]-[202].

99 Dow Jones Inc v Gutnick (2003) 77 ALJR 255; 194 ALR 433.

100 Discussed in D Harris, A New Constitution for Australia (2002); see also Human Rights - the Australian Debate (1987); M R Wilcox, An Australian Charter of Rights? (1993).

${ }^{101}$ Pursuant to the Australian Constitution, s 128. A proposal to incorporate "one vote one value" was rejected by a majority of the electors in every State and secured a national

Footnote continues 
achieving formal constitutional change ${ }^{102}$ (which is as conservative in this respect as that of the United States), the prospect of a constitutional bill of rights for Australia in the short term seems remote. More likely is it that individual States and Territories, and eventually the Federal Parliament, will enact general human rights legislation out of which, in the long term, a successful constitutional amendment may emerge. It will not be soon.

\section{Use of international law:}

Partly as a consequence of the last consideration, there has been a tendency in recent years to look to international human rights law to inform the development of Australia's domestic law. In 1988, I suggested that this was a development with a large potential. ${ }^{103}$ At the time, my suggestion was regarded as legal heresy. Eventually, the High Court of Australia accepted the possibility that international human rights instruments, to which Australia was a party, might influence the development of the common law. This occurred in an important decision of the High Court of Australia, delivered before my appointment, reversing more than a century of judicial decisions denying recognition of the claims of Australia's indigenous peoples to legal interests in their traditional land. ${ }^{104}$

More recently, I have suggested that the Australian Constitution itself should be read, in the event of ambiguity, so as to avoid departures from the fundamental norms of international law, specifically in the area of human rights. ${ }^{105}$ For some time, this approach remains controversial. ${ }^{106}$ However, there

affirmative vote of only 37.10\%; cf McGinty v Western Australia (1996) 186 CLR 140. A proposal to include guarantees of trial by jury, religious freedom and just terms in matters of State concern was rejected in every State and secured an aggregate national affirmative vote of only $30.33 \%$.

${ }^{102}$ In 103 years, 44 proposals have been put to the Australian electors for the amendment of the Australian Constitution. Only 8 have succeeded: A R Blackshield and G Williams Australian Constitutional Law and Theory (3rd ed, 2002), 1301.

${ }^{103}$ M D Kirby "The Australian Use of International Human rights Norms: From Bangalore to Balliol - A View from the Antipodes" (1993) 16 University of NSW Law Journal 363; M D Kirby, "Law, Like the Olympics, is Now International - But Will Australia Win Gold?” (2000) 7 James Cook Uni L Rev 4 at 13-15.

${ }^{104}$ Mabo v Queensland [No 2] (1992) 175 CLR 1 at 42.

${ }^{105}$ Newcrest Mining (WA) Ltd $v$ The Commonwealth (1997) 190 CLR 513 at 655-657 (acquisition of property); Kartinyeri $v$ The Commonwealth (1998) 195 CLR 337 at 417419 [166]-[167] (racial discrimination). See also Wilson v Minister for Aboriginal and Torres Strait Islander Affairs (1996) 189 CLR 1 at 40 (separation of judicial powers). 
are reflections of it in the recent decisions of the Supreme Court of the United States. ${ }^{107}$ Some Australian judges and lawyers would probably agree with the spirit of the dissenting opinions of Justice Scalia in those cases. ${ }^{108}$ However, the adjustment of municipal law to avoid disharmony with international law is a challenge that final courts of appeal everywhere will have to face in the course of the present century. The last words on this subject have not been written.

Interpretation of original intent:

In Australia, as in the United States, there have been lively debates, concerning the extent to which the interpretation of the written text of the Constitution is governed by the original intent of the founders or whether the text is released from their intentions, the task being one of finding the meaning of the Constitution, "set free" from the assumptions and purposes of those who wrote it $^{109}$

In the United States, possibly because of the revolutionary origins of the Constitution, the diversity of the country, the size of the population and the disparity of its legal organisation, many have felt, with Thomas Jefferson, that "the country's peculiar security is in the possession of a written Constitution." The constitutional text in the United States has attracted much greater reverence than the Australian document has done. One has a feeling that much more attention is given in the United States to the historical facts as they existed at the time between 1787 and 1788 when the Constitution was adopted expressing the basic beliefs and values of those who had declared their independence from Britain $^{110}$. Although, in Australia, it is common for the High Court to examine understandings about the language of the Constitution, held when the document was drawn up ${ }^{111}$, and specifically to scrutinise the debates in the Conventions that

${ }^{106}$ K Walker “International Law as a Tool of Constitutional Interpretation “ (2002) 28 Monash University Law Review 83; L Johns, "Justice Kirby, Human rights and the Exercise of Judicial Choice” (2001) 27 Monash University Law Review 290.

107 Atkins v Virginia 536 US 000 (2002) per Stevens J (fn); 122 SCt 2242 (2002); Lawrence $v$ Texas (2003).

108536 US 000 (2002) at 000 per Scalia J, 122 SCt 2242 (2002). He had expressed like views in Stanford $v$ Kentucky 492 US 361 at 369 fn 1 (1989); cf Kartinyeri $v$ The Commonwealth (1998) 195 CLR 337 at 383-386 [95]-[109]; AMS v AIF (1999) 199 CLR 160 at 180 [50]; cf 218 [168]-[169].

109 Andrew Inglis Clark Studies in Australian Constitution Law (1901), 21 cited in Re Wakim; Ex parte McNally (1999) 198 CLR 511 at 600-601.

${ }^{110}$ See eg Dred Scott $v$ Sandford 60 US 393 at 407-408 (1857) per Taney CJ.

111 cf Grain Pool of Western Australia v The Commonwealth (2000) 202 CLR 479 at 523 [111]. In that case much attention was paid to the provisions of the US Constitution Art 
preceded the adoption of the Constitution (a course which until recently was regarded as impermissible), ${ }^{112}$ it is generally recognised that the elucidation of constitutional meaning involves more than a purely historical exercise. In a sense, this recognition has been reinforced by the rigidities of the Australian Constitution and the difficulty of securing its formal amendment.

A good illustration of adaptation of the meaning of constitutional words in Australia may be found in the decision of the High Court in Sue v Hill. ${ }^{113}$ There, the question involved the meaning of a provision in the Constitution excluding from election to the Federal Parliament any person who was "a subject or a citizen ... of a foreign power." There could be no doubt that, in 1900 when the Australian Constitution was adopted, the United Kingdom would not have been regarded as a "foreign power". There are too many references in the Constitution to the United Kingdom, and to the status of subjects of the Crown, ${ }^{114}$ to attribute such a meaning to the text. Nevertheless, at the end of the twentieth century, the High Court held that a person who was a citizen of the United Kingdom was disqualified from election to the Australian Federal Parliament whilst she retained that separate citizenship. In short, she was a "citizen of a foreign power". The result was one that would have struck the founders of the Australian Commonwealth as astonishing. The notion that the High Court should give meaning to the Constitution strictly in accordance with the original intent of the founders is not one that accords with the overall practice of the High Court of Australia. ${ }^{115}$ Nor, in my view, is it one appropriate to constitutional interpretation in a final court with those responsibilities.

\section{Diversity and opinion writing:}

There are differences in matters of detail in the work of the two supreme courts. My court has not adopted the style, followed in the United States Supreme Court, by which an opinion of the Court is written by a single Justice assigned by the Chief Justice or, if he is in a minority, by the senior Associate Justice. Although unanimous opinions are sometimes achieved in the Australian

I, s 8 , cl 8 that sustain patents of invention, the expression in the Australian Constitution, s 51(xviii). See ibid, at 479-480 [28]-[32], 532 [134].

112 Cole $v$ Whitfield (1988) 165 CLR 360 at 385-390.

113 (1999) 199 CLR 462.

114 eg Australian Constitution, ss 34(i), 117.

115 M D Kirby "Constitutional Interpretation and Original Intent - A Form of Ancestor Worship?” (2001) 24 Melbourne University Law Review 1; J Kirk, “Constitutional Interpretation and a theory of Evolutionary Originalism” (1999) 27 Federal Law Review 323. 
High Court, including in important constitutional cases, ${ }^{116}$ ordinarily, the arrangements for the writing of opinions are much more informal. A system of formal consultation after hearings has been introduced in recent times. However, there continue to be large numbers of separate concurring and dissenting opinions. This has long been the tradition of the English courts, other than the Judicial Committee of the Privy Council.

In Australia, the inclination of judges to join in the opinions of their colleagues varies over time, depending, in part, on personal relations and shared legal and philosophical viewpoints. In effect, multiple opinions enhance the creative element in the law. They respect the independence of individual Justices. On the other hand, they can sometimes obscure the binding rule for which a court's decision will stand. They sometimes create inefficiency and uncertainty in the judiciary and legal profession. ${ }^{117}$ The United States practice, introduced by Chief Justice Marshall, has much to commend it. There are similar practices in intermediate appellate courts in Australia. But, so far, the practice has not been copied in the High Court of Australia.

Another precedent that has not been copied is that of the reported practice of some Justices of the Supreme Court of the United States in delegating to clerks the writing of a first draft of judicial opinions. I am not aware that this has ever occurred in the case of a Justice of the High Court of Australia, although the clerks ("associates") are often asked to perform particular tasks of legal research and to provide comments and criticisms upon the first draft prepared by the Justice.

In the 1930s, Justice Brandeis remarked that the reason why the Justices of the Supreme Court enjoyed such a high reputation in Washington was that "we are the only people who do our own work" ${ }^{118}$ Inflexibility in the adherence to the ways of the past is not necessarily a matter for pride. I have long thought that common law courts should study the procedures of some courts of the civil law tradition in which a greater part of the writing of the facts, analysis of the issues and the presentation of the synthesis of the arguments could be performed by officials. This would leave to the Justices the truly difficult task of decisionmaking. Traditionalists oppose such suggestions, pointing out, correctly, that the presentation of the facts and issues in a case can sometimes profoundly affect the

\footnotetext{
116 eg Cole $v$ Whitfield (1988) 165 CLR 360; Lange $v$ Australian Broadcasting Corporation (1997) 189 CLR 520.

${ }^{117}$ C Moisidis, “Achieving World's Best Practice in the Writing of Appellate Judgments” (2002) 76 Law Institute Journal (Victoria), 30 at 32.

118 Justice Brandeis quoted C E Wyzanski "The Law of Change”, Lecture at University of Mexico School of Law (1968) cited in M D Kirby The Judges, (1983), 41 (Boyer Lectures 1983, 25-26).
} 
outcome of the case. However, as the workload of courts increases and substantial numbers of important cases are remitted to other decision-makers for arbitration, mediation or assessment, it may eventually become necessary (even in a final court) to reconsider some of the familiar ways of doing things. For the time being, in the Australian High Court, we remain resolutely tied to the traditional ways.

\section{CONCLUSIONS}

Five influential ideas:

A reflection on the similarities and differences between the High Court of Australia and the Supreme Court of the United States will indicate that the similarities are profound and predominate. The differences are less so. Both courts serve vibrant, democratic societies and advanced economies. Both share the heritage of the common law. Both courts uphold federal constitutional arrangements in independent judicial institutions whose orders are obeyed without question and without, for the most part, any need of physical enforcement.

Of the five great legal ideas of the founders of the United States of America four, at least, have proved successful exports. One, the executive presidency, combining the roles of head of state, head of government and commander in chief, has not been widely adopted. Australia, like a majority of countries, continues to follow the system of responsible, cabinet government. Virtually no one in Australia suggests a change in this respect. To most outsiders the American model seems, in this respect, a flawed system, overly influenced by the example of the centralised monarchy of King George III in $1776^{119}$ and too little reflective of the modern needs for collective government with general harmony between the branches of government, difficult to achieve under the United States Constitution. ${ }^{120}$ The constitutional monarch continued to evolve after 1776 . The evolution did not affect the United States Constitution.

The republican idea, on the other hand, has been highly successful. Although Australia remains a constitutional monarchy, ${ }^{121}$ most other nations since 1776

${ }^{119}$ O Dixon "Government under the American Constitution”, in Jesting Pilate 106 at 111. ${ }^{120}$ O Dixon "Two Constitutions Compared” in Jesting Pilate, 100 at 101.

${ }^{121}$ A referendum for the alteration of the Australian Constitution to create a republic was put to the electors on 6 November 1999. The affirmative national vote was $44.74 \%$ with $54.40 \%$ against. The referendum did not secure a majority in a single State: It therefore failed to pass. See G Williams, "Why Australia Kept the Queen" (2000) 63 Saskatchewan Law Review 477. 
have abolished their monarchies. Even constitutional monarchies embrace the civic ideals of republicanism. They retain the symbols of monarchy as useful further checks on the abuse of elected power. ${ }^{122}$ But, in their essential character, they are republics.

The Bill of Rights idea, quickly incorporated into the original amendments to the United States Constitution, has also proved a powerful influence not only in national constitutions but in the growing number of international instruments that uphold fundamental rights - economic, social and cultural as well as civil and political. Australia remains outside the systems of national and regional human rights charters. But it is a party to - and its law is influenced by - the many international human rights treaties to which it has subscribed.

The federal idea was the most complex of the innovations of the American founders. A number of federal states, including some created after the end of British colonial rule, have collapsed. ${ }^{123}$ Others have proved unstable. Yet on the whole the federations of the United States and Australia (and of Canada, India and elsewhere) have been successful examples of the division and decentralisation of legal and political power. There is an inherent tension between federalism and responsible government which is still being played out in Australia. But it is difficult to imagine how nations of the physical size of Australia or the United States could have been successfully, justly and efficiently governed without adopting a federal system. For it, Australians are indebted to the American model whose division of governing powers largely shaped their own.

The greatest constitutional export after the American Revolution of 1776, and the settlement that followed it, has been the establishment by a written constitution of an independent Judicature with defined powers as the ultimate arbiter of constitutionalism and defender of the rule of law. In Australia, this precedent was faithfully followed. The High Court of Australia was created, substantially, to play the part that the Supreme Court plays in the United States. In a sense, the High Court of Australia, like other courts of many later nations, has built upon the great traditions of the United States court. It continues to do so.

In every country, but particularly every federal country, the ideas written by Chief Justice Marshall in 1803 in Marbury $v$ Madison $^{124}$ continue to inform

\footnotetext{
122 cf O Dixon "The Law and the Constitution” in Jesting Pilate 40-41.

123 eg the original Pakistan; the Central African Federation and the original Malaysian Federation (including Singapore). The Soviet Union, Czechoslovakia and Yugoslavia were also federal states that broke up in recent years. Nigeria fought off the separation of Biafra to survive intact, just as the United States did in its Civil War.

1241 Cranch (5 US) 137 (1803).
} 
decisions about the concept of the judicial role in a modern state. The export of these ideas, and many others inherent in them, are abiding contributions of the judges and lawyers of the United States to constitutionalism as it continues to develop in all parts of the world.

Global constitutionalism:

The end of this story is not yet written. Future chapters may reveal that some of the younger nations, that borrowed many of the governmental ideas nurtured in the United States, came in time to repay part of their debt. In today's world, more than before, we can, and should, learn from each other, even in matters of constitutional law. In a sense, this is another American idea - that the imperialism of power and money gives way, in the end, to the liberty of shared experience and the unstoppable influence of new ideas. 